\title{
Effects of different irrigation frequencies and incorporation of rice straw on yield and water productivity of wheat crop
}

\author{
Mazhar Hussain Tunio ${ }^{1,2}$, Jianmin Gao ${ }^{1 *}$, Mashooque Ali Talpur², Imran Ali Lakhiar ${ }^{1}$, \\ Farman Ali Chandio ${ }^{1,2}$, Sher Ali Shaikh ${ }^{1,2}$, Kashif Ali Solangi ${ }^{1}$ \\ (1. School of Agricultural Equipment Engineering, Jiangsu University, Zhenjiang 212013, China; \\ 2. Sindh Agriculture University, 70060 Tando Jam, Pakistan)
}

\begin{abstract}
The current rapid increase in irrigation water consumption is considered unsustainable and threatens the world food production. Therefore, it is mandatory to promote modern techniques and to manage existing conventional irrigation methods. The present study was attempted to determine the effects of different irrigation frequencies and rice straw incorporation rates on yield and water productivity of the wheat crop. The experiment was arranged with randomize complete block design involving nine treatments $\left(\mathrm{RS}_{0} \mathrm{I}_{7}, \mathrm{RS}_{0} \mathrm{I}_{15}, \mathrm{RS}_{0} \mathrm{I}_{22}, \mathrm{RS}_{1} \mathrm{I}_{7}, \mathrm{RS}_{1} \mathrm{I}_{15}, \mathrm{RS}_{1} \mathrm{I}_{22}, \mathrm{RS}_{2} \mathrm{I}_{7}, \mathrm{RS}_{2} \mathrm{I}_{15}\right.$ and $\left.\mathrm{RS}_{2} \mathrm{I}_{22}\right)$ under three replications. Results exposed that the incorporation of rice straw with different irrigation frequencies significantly improved physico-chemical properties of soil. Moreover, soil bulk density, infiltration rate, $\mathrm{pH}$, electrical conductivity significantly decreased and soil porosity significantly increased under all treatments. Furthermore, maximum crop yield and crop water productivity of $7706.4 \mathrm{~kg} / \mathrm{hm}^{2}$ and $1.92 \mathrm{~kg} / \mathrm{m}^{3}$ respectively were found under $\mathrm{RS}_{1} \mathrm{I}_{15}$ treatment. Based on experimental results it can be concluded that irrigation frequency and incorporation of rice straw had significant effects on the physico-chemical properties of soil, total grain yield and water productivity of the wheat crop. However, this study suggested that the wheat crop yield and water productivity could be increased by incorporating $1 \mathrm{t} / \mathrm{hm}^{2}$ rice straw with $15 \mathrm{~d}$ of irrigation frequency.
\end{abstract}

Keywords: physico-chemical, irrigation frequency, rice straw, wheat, crop water productivity

DOI: $10.25165 /$ j.ijabe. 20201301.4790

Citation: Tunio M H, Gao J M, Talpur M A, Lakhiar I A, Chandio F A, Shaikh S A, et al. Effects of different irrigation frequencies and incorporation of rice straw on yield and water productivity of wheat crop. Int J Agric \& Biol Eng, 2020; 13(1): $138-145$.

\section{Introduction}

Pakistan is the sixth most heavily populated country in the world, with a current population of 202.086 million and an annual growth rate of $1.93 \%$. The population has increased from 32.4 million in mid of 1948 to 144.5 million in 2003, and exceeded 168 million in 2010. The estimated population for the year 2025 would be 226.76 million $^{[1]}$. In addition, agriculture in Pakistan is considered as a central pillar of the country. The importance of agriculture to Pakistan's economy is explained by the fact that agricultural outputs contribute to $24.7 \%$ of the gross domestic production (GDP) and employs $47.3 \%$ of the employment strength of Pakistan. Wheat, cotton, rice and maize are the major crops ${ }^{[2]}$.

Wheat (Triticum aestivum L.) is an essential staple food crop in Pakistan that constituted $9 \%$ of household consumption, and it is also cultivated at a large scale throughout the country. In rural

Received date: 2018-11-19 Accepted date: 2019-11-20

Biographies: Mazhar Hussain Tunio, PhD candidate, Lecturer, research interests: irrigation engineering, Email: mazharhussaintunio@sau.edu.pk; Mashooque Ali Talpur, Associate Professor, research interests: irrigation engineering, Email: mashooq talpur@yahoo.com; Imran Ali Lakhiar, PhD candidate, research interests: fog tilling, Email: 5103160321@stmail.ujs.edu.cn; Farman Ali Chandio, Associate Professor, research interests: agricultural machinery, Email: farman@ujs.edu.cn; Sher Ali Shaikh, PhD candidate, Lecturer, research interests: agricultural machinery, Email: sashaikh@sau.edu.pk: Kashif Ali Solangi, $\mathrm{PhD}$ candidate, research interests: soil salinity control, Email: 5103180312@stmail.ujs.edu.cn.

*Corresponding author: Jianmin Gao, Professor, research interests: Soil \& fog tilling, No 301 Xuefu road, Zhenjiang city, Jiangsu Province, China; Tel: +86-13655282069, Email: gaojianminujs@163.com. households, wheat is consumed at a high level compared to the urban household, whereas it was considered as the second most consumed commodity. However, its yield had been significantly affected by many issues like shortage of water, increases in prices of agricultural input and droughts over years and challenges of low wheat production in Pakistan are still considerable. It is also discussed by other scientists that the low grain yield could be mainly due to the increased moisture scarcity from sowing throughout the growing season, which adversely affects plant growth and development ${ }^{[3]}$.

In Pakistan, the wheat crops growing season starting from October to April (Rabi) period and in this time abundant amount of water is required for agriculture use. However, the sever scarcities of water intimidate the opportunity to satisfy those necessities ${ }^{[4]}$. The current rapid increase in irrigation water use is considered unsustainable and threatens future food production ${ }^{[5-7]}$. Therefore, effectual applying of the available water is required if higher agriculture production is desired, and the wise use of water can contribute to more crop output ${ }^{[8-10]}$. Irrigation plays an essential role in improving the productivity of wheat crop. Khokhar et al. ${ }^{[1]}$ investigated the consequences of irrigation frequency on water use and yield of wheat, and found that $8.01 \mathrm{~kg} / \mathrm{hm}^{2} \cdot \mathrm{mm}$ of wheat yield was obtained when field was watered after every $35 \mathrm{~d}$ interval. Karrou et al. ${ }^{[12]}$ evaluated the performance of deficit irrigation of wheat by comparing with farmer's practice and full irrigation revealed that deficit irrigation showed $1500 \mathrm{~m}^{3} / \mathrm{hm}^{2}$ water saving in wheat compared to the farmer's practice and full irrigation. Another research found that $2 \mathrm{~d}$ and $6 \mathrm{~d}$ irrigation frequencies plots gave better performance 
compared to $4 \mathrm{~d}$ irrigation ${ }^{[13]}$. In Pakistan, sustainable agriculture depends entirely on water availability ${ }^{[14]}$, and there is a high potential for improving crop water productivity. The crop water productivity may be achieved by reducing runoff, soil evaporation, plant transpiration and drainage loss using anti transpiration materials.

Rice straw is mostly applied to improve the soil physico-chemical properties ${ }^{[15-17]}$ while minimize the impact of agrochemicals, which is an important concern in current agricultural activities ${ }^{[18]}$. Similarly, straw incorporation increased crop production by refining soil physical circumstances and stability down to $30 \mathrm{~cm}$ soil profile ${ }^{[19]}$ and improving the quality of wheat grain significantly ${ }^{[20]}$. It increases the infiltration and storing of water in the rhizosphere and improved structure and macro-porosity of soil ${ }^{[21]}$. Tolk et al. ${ }^{[22]}$ revealed that the wheat grain yield can be generally increased by the reduction of surface evaporation, which increases soil moisture content. Rice straw resulted in $17 \%$ increases in grain yield and 19\% in above ground biomass. Yan-min et al. ${ }^{[23]}$ reported that plant height was found higher at field with $8 \mathrm{t} / \mathrm{hm}^{2}$ rice straw mulching rate compared with zero rice straw mulched soil, the weight of grains and grain yield $/ \mathrm{hm}^{2}$ peaked at $6 \mathrm{t} / \mathrm{hm}^{2}$ rice straw mulching rate. There was also research ${ }^{[24]}$ studied the effect of rice straw mulching on production of wheat and concluded that rice straw mulching enhanced plant height and number of grains, improved wheat production both qualitatively and quantitatively. Chaudhary et al. ${ }^{[25]}$ conducted field trials to study the rice straw mulching at different doses at the rates of $7.5,10.0,12.5,15.0,17.5$ and $20.0 \mathrm{t} / \mathrm{hm}^{2}$, respectively, with no rice straw field as a control plot. They concluded that rice straw was an alternate source as a soil fertility supplement. Mousavi et al. ${ }^{[26]}$ found that the treatments with rice straw mulch (RSM) led to a significant increase in water holding capacity, field capacity, water productivity and available water. Similarly, the rice straw decreased consumption of water from $7.18 \mathrm{~L} /$ plot (control) to $7.05 \mathrm{~L} /$ plot.

Based on the above researches, this study was planned to evaluate the effect of different rice straw mulching rates and different irrigation frequencies on yield and water productivity, aimed to further improve the wheat production and soil physical properties.

\section{Materials and methods}

\subsection{Location of experimental site}

The field research was conducted during the year 2015-16, at the tentative place of the Department of Irrigation and Drainage, Faculty of Agricultural Engineering, Sindh Agriculture University at Tandojam, Sindh, Pakistan. The study area was located at Latitude $25^{\circ} 25^{\prime} 28^{\prime \prime} \mathrm{N}$ and Longitude $68^{\circ} 32^{\prime} 26^{\prime \prime} \mathrm{E}$, and at an elevation of about $26 \mathrm{~m}$ above mean sea level (MSL). The detail location was shown in Figure 1.

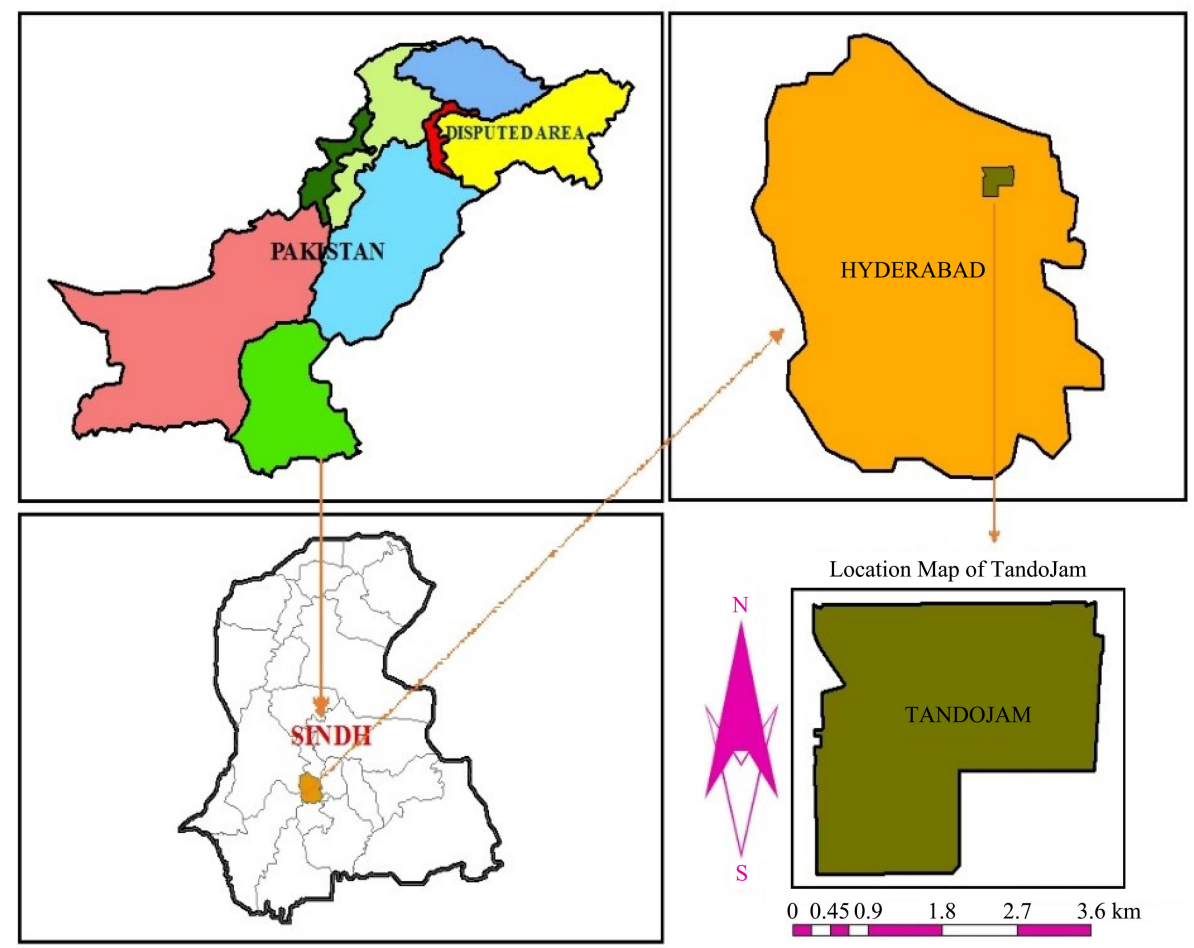

Figure 1 Geographical location of the experiment field site

\subsection{Climate condition}

The experimental area has a mostly semi-arid climate. Annual rainfall is $145-155 \mathrm{~mm}$, which is lower than potential evapotranspiration. More than $90 \%$ of the rainfall was received during summer monsoon period July-Sep, and meager rain occurred due to rare westerly waves that extend to the southern parts of the country. It is impossible to conduct crop production in this area without irrigation. The experimental area was situated in southern parts of Sindh, which was slightly cooler and more humid than the northern parts due to the Arabian Sea. Temperature ranges from cool to cold in winter and from hot to very hot during summer. The monthly distributions of the maximum and minimum temperatures and rainfall during 2015-2016 at the experimental site were illustrated in Figure 2.

\subsection{Experimental design}

The research was piloted to evaluate the effect of different rice straw mulching rates and different irrigation frequencies on yield and water productivity of the wheat crop. The experiment was laid out in a split plot with randomize complete block design as shown in Figure 3a. For this purpose, the total experiment site of $833 \mathrm{~m}^{2}(17 \times 49)$ was divided into $27 \mathrm{sub}$ plots of $25 \mathrm{~m}^{2}(5 \times 5)$ each. The research comprised with nine treatments, including 
three different irrigation frequencies of $7 \mathrm{~d}\left(\mathrm{I}_{7}\right), 15 \mathrm{~d}\left(\mathrm{I}_{15}\right)$, and $22 \mathrm{~d}$ $\left(\mathrm{I}_{22}\right)$ and three different rice straw mulching rates of no rice straw, rice straw at $1 \mathrm{t} / \mathrm{hm}^{2}$, and $2 \mathrm{t} / \mathrm{hm}^{2}$. Each treatment was conducted with three replications. A complete explanation of the treatments was displayed in Table 1 .

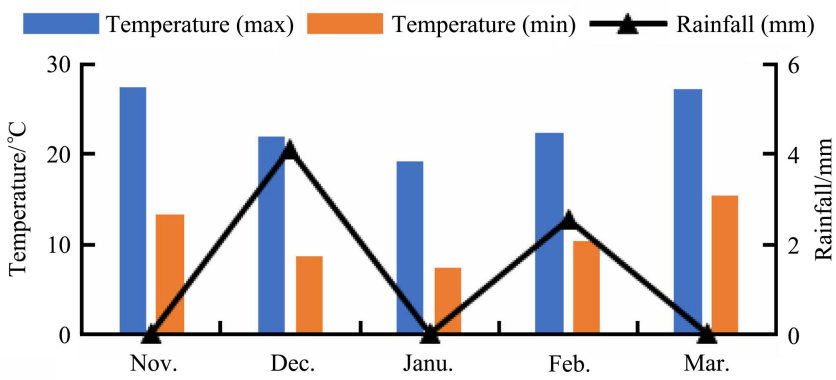

Figure 2 Monthly mean temperature $\left({ }^{\circ} \mathrm{C}\right)$ and rainfall $(\mathrm{mm})$ during the experiment

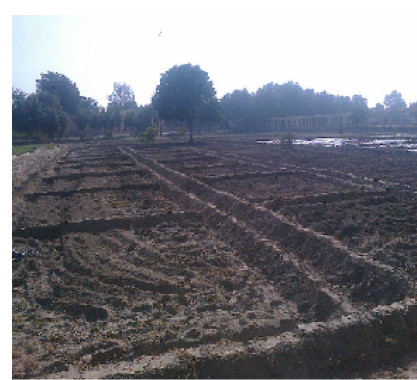

a. Plots

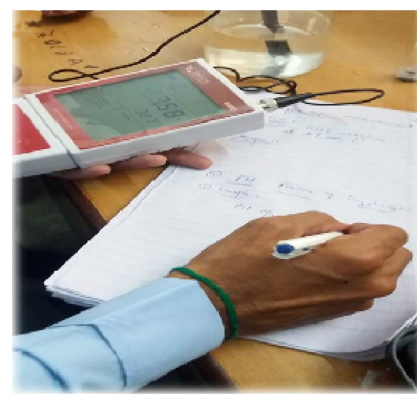

c. Digital pH meter

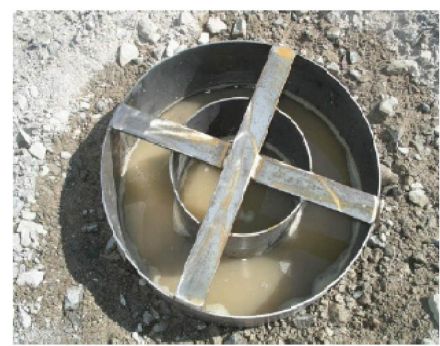

e. Double ring infiltrometer

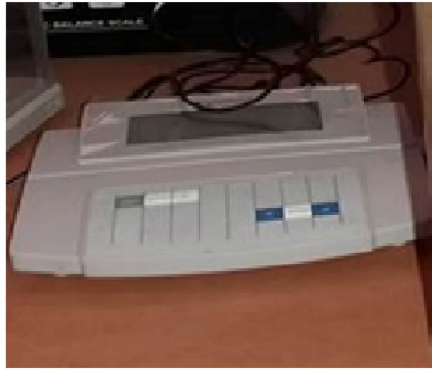

b. digital EC meter

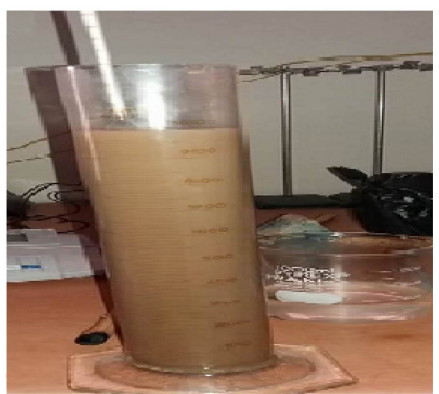

d. Hydrometer

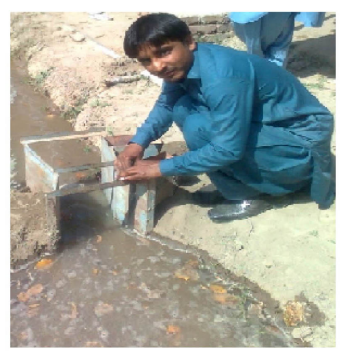

f. Cut-throat flume
Figure 3 Experimental setup and equipment used during the study

Table 1 Detailed description of different irrigation frequencies and rice straw mulching rates

\begin{tabular}{clc}
\hline Treatments & \multicolumn{1}{c}{ Descriptions } & Symbols \\
\hline T1 & No rice straw and 7 d of irrigation frequency & $\mathrm{RS}_{0} \mathrm{I}_{7}$ \\
T2 & No rice straw and 15 d of irrigation frequency & $\mathrm{RS}_{0} \mathrm{I}_{15}$ \\
T3 & No rice straw and 22 d of irrigation frequency & $\mathrm{RS}_{0} \mathrm{I}_{22}$ \\
T4 & Rice straw at $1 \mathrm{t} / \mathrm{hm}^{2}$ and 7 d of irrigation frequency & $\mathrm{RS}_{1} \mathrm{I}_{7}$ \\
T5 & Rice straw at $1 \mathrm{t} / \mathrm{hm}^{2}$ and 15 d of irrigation frequency & $\mathrm{RS}_{1} \mathrm{I}_{15}$ \\
T6 & Rice straw at $1 \mathrm{t} / \mathrm{hm}^{2}$ and 20 d of irrigation frequency & $\mathrm{RS}_{1} \mathrm{I}_{22}$ \\
T7 & Rice straw at $2 \mathrm{t} / \mathrm{hm}^{2}$ and 7 d of irrigation frequency & $\mathrm{RS}_{2} \mathrm{I}_{7}$ \\
T8 & Rice straw at $2 \mathrm{t} / \mathrm{hm}^{2}$ and 15 d of irrigation frequency & $\mathrm{RS}_{2} \mathrm{I}_{15}$ \\
T9 & Rice straw at $2 \mathrm{t} / \mathrm{hm}^{2}$ and 22 d of irrigation frequency & $\mathrm{RS}_{2} \mathrm{I}_{22}$ \\
\hline
\end{tabular}

\subsection{Soil sampling and analyzing}

In order to determine the physico-chemical properties of soil, 81 core soil samples were collected from the experimental field at the depths of $0-20 \mathrm{~cm}, 21-40 \mathrm{~cm}$ and $41-60 \mathrm{~cm}$ respectively with the help of tube auger. The soil samples were collected, packed and brought to the laboratory of Irrigation and Drainage department for analyzing. The same procedure was repeated before and after the harvesting of wheat crop. These soil samples were examined for texture, bulk density, porosity, PH and EC determination.

\subsubsection{Soil texture}

The infiltration rate and water holding capacity of the soil are mostly biased on soil texture. In this study, Bouyoucos Hydrometer technique ${ }^{[27]}$ was used to calculate the particle size distribution as shown in Figure 3d.

\subsubsection{Soil bulk density}

For determination of dry bulk density of the soil, the composite soil samples were carried out from the plots of experimental field at the depths of $0-60 \mathrm{~cm}$ with the help of tube auger of known diameter. These samples were labeled, packed and brought to the laboratory and calculated the wet weight with electric balance. Samples were placed in a $105^{\circ} \mathrm{C}$ oven for $24 \mathrm{~h}$, and then dry weight of each sample was measured. The soil dry bulk density of the soil was calculated by Equation (1) ${ }^{[28]}$.

$$
\text { Dry bulk density }\left(\rho_{d}\right)=\frac{\text { Dry weight of soil sample }}{\text { Total volume of soil sample }}
$$

\subsubsection{Soil porosity}

The soil porosity was determined by Equation (2) given by Kanwar and Chopra ${ }^{[29]}$.

$$
D=\frac{V_{V}}{V_{T}} \times 100
$$

where, $D$ is porosity, $\%$; $V_{v}$ is the total volume of voids in the aggregates; $V_{t}$ is the total bulk volume of aggregates.

\subsubsection{Infiltration rate}

To determine the infiltration rate, a double ring infiltrometer was used to determine infiltration rate before and after the experiment of soil under saturated conditions. The procedure was adopted by Bouwer ${ }^{[30]}$ and Daniel ${ }^{[31]}$ as shown in Figure 3e.

\subsubsection{Soil $\mathrm{pH}$ and $\mathrm{EC}$}

For determination of $\mathrm{pH}$ of soil samples, $20 \mathrm{~g}$ of soil sample was weighed and added into $50 \mathrm{~mL}$ distilled water. The suspension was stirred for $15 \mathrm{~min}$ and allowed to settle for $30 \mathrm{~min}$ and again stirred for $2 \mathrm{~min}$. After that, $\mathrm{pH}$ was recorded by immersing electrode of digital $\mathrm{pH}$ meter as shown in Figure $3 \mathrm{~b}$. EC was measured in 1:2 soil-water suspension by conductivity meter as shown in Figure 3c.

\subsection{Irrigation water quality}

In order to control the quality of irrigation water, three water samples were collected after 10,20 and 30 min intervals and taken to the laboratory of Irrigation and Drainage department for the determination of $\mathrm{EC}_{\mathrm{W}}, \mathrm{pH}$ and sodium absorption ratio (SAR). Equation (3) adopted by Rowell ${ }^{[32]}$ was used to calculate the SAR.

$$
\mathrm{SAR}=\frac{\mathrm{Na}^{+}}{\sqrt{\frac{\mathrm{Ca}^{++}+\mathrm{Mg}^{++}}{2}}}
$$

where, $\mathrm{Na}^{+}$is Sodium; $\mathrm{Ca}^{++}$is Calcium; $\mathrm{Mg}^{++}$is Magnesium.

\subsection{Irrigation plan for all treatments}

The study was carried at three irrigation frequencies $7 \mathrm{~d}, 15 \mathrm{~d}$ and $22 \mathrm{~d}$. To apply the required depth of water to plots, a cut-throat flume $\left(8^{\prime} \times 1.5\right.$ ') was installed at the center of field channel at the time of irrigation as shown in Figure $3 \mathrm{f}$. To 
determine the flow rate, Equation (4) was used ${ }^{[33]}$.

Formula for free flow (if $H_{d} / H_{u}<0.68$ )

$$
Q_{f}=3.99\left(h_{u}\right)^{1.939}
$$

The amount of irrigation water required was calculated by Equation $(5)^{[34,35]}$

$$
D=\frac{S M D}{100} \times \rho_{b} \times d_{r}
$$

where, $D$ is the depth of water required, $\mathrm{cm} ; S M D$ is soil moisture deficit level; $\rho_{b}$ is bulk density, $\mathrm{g} / \mathrm{cm}^{3} ; d_{r}$ is root depth, $\mathrm{cm}$.

The time of irrigation application to required depth of water was calculated by Equation $(5)^{[36,37]}$.

$$
Q T=28 \times A \times D
$$

where, $Q$ is discharge required (LPS); $T$ is time of application, h; $A$ is area to be irrigated, $\mathrm{hm}^{2} ; D$ is the depth of irrigation to be applied, $\mathrm{cm}$.

\subsection{Sowing and yield of wheat crop}

The wheat crop was sown in basin irrigation method under all treatments after $100 \mathrm{~mm}$ socking doze. When the soil was reached at the field capacity condition; a wheat variety of Tando Jam-83 (TJ-83) was sown in the experimental plots. Wheat crop was collected in bags after harvest and weighed for yield calculation.

\subsection{Water productivity}

Water productivity (WP) under all treatments was calculated by Equation (7).

$$
W P=\frac{Y}{I}
$$

where, $W P$ is water productivity, $\mathrm{kg} / \mathrm{m}^{3} ; Y$ is yield, $\mathrm{kg} ; I$ is irrigated water, $\mathrm{m}^{3}$.

\subsection{Statistical analysis}

To evaluate the significance and interactions of different irrigation frequencies and straw mulching rates on soil physicochemical properties, crop yield and water productivity, analysis of variance (ANOVA) was used. The means were compared using Duncan's multiple range test, with $p<0.05$ level being considered significant. All statistical analyses were conducted using IBM Statistical Package for Social Scientists (SPSS 18.0).

\section{Results}

The present research was conceded to determine the effects of different rice straw mulching rates and different irrigation frequencies on yield and water productivity of the wheat crop. To achieve the proposed objectives of the research study the results of the following parameters are described in detail.

\subsection{Soil physico-chemical properties}

\subsubsection{Soil texture}

The textural class of soil profile before the experiment was clay loam at all depths. After wheat growth, the textural classes

\begin{tabular}{|c|c|c|c|c|c|c|c|c|c|}
\hline \multirow{2}{*}{ S No } & \multicolumn{5}{|c|}{ Before Experiment } & \multicolumn{4}{|c|}{ After Experiment } \\
\hline & Depth/cm & Sand $/ \%$ & Silt/\% & Clay $/ \%$ & Textural Class & Sand $/ \%$ & Silt $/ \%$ & Clay $\%$ & Textural Class \\
\hline 1 & $0-20$ & 28.8 & 45.6 & 25.6 & Clay Loam & 30.2 & 42.9 & 26.9 & Clay Loam \\
\hline 2 & $21-40$ & 28.8 & 48.4 & 22.8 & Clay Loam & 30.8 & 45.4 & 23.8 & Clay Loam \\
\hline 3 & $41-60$ & 28.8 & 45.6 & 25.6 & Clay Loam & 25.8 & 42.3 & 31.9 & Clay Loam \\
\hline
\end{tabular}
of the soil profile remained unchanged. The results of soil particles percentages were presented in Table 2 .

Table 2 Soil texture before and after the experiment at various depths

\subsubsection{Soil bulk density}

The results of the average soil dry bulk density of the soil horizons of experimental field up to $60 \mathrm{~cm}$ depth were presented in Figure 4. After experiment, soil bulk density significantly decreased $(p<0.05)$ under all treatments. The maximum reduction of the bulk density of $7.3 \%$ was obtained under $\mathrm{RS}_{2} \mathrm{I}_{15}$ treatments, whereas the smallest reduction of $2.99 \%$ occurred under $\mathrm{RS}_{0} \mathrm{I}_{15}$ and $\mathrm{RS}_{2} \mathrm{I}_{22}$ treatments, respectively.

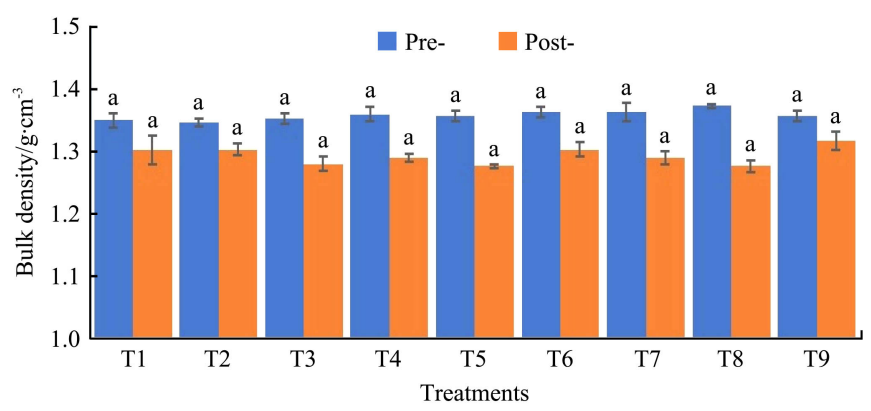

Note: $\mathrm{T} 1(\mathrm{RS} 0 \mathrm{I} 7)=$ no RS with $7 \mathrm{~d}$ of irrigation frequency, $\mathrm{T} 2\left(\mathrm{RS}_{0} \mathrm{I}_{15}\right)=$ no RS with $15 \mathrm{~d}$ of irrigation frequency, T3( $\left.\mathrm{RS}_{0} \mathrm{I}_{22}\right)=$ no RS with $22 \mathrm{~d}$ of irrigation frequency, T4 $\left(\mathrm{RS}_{1} \mathrm{I}_{7}\right)=\mathrm{RS} @ 1 \mathrm{t} / \mathrm{hm}^{2}$ with $7 \mathrm{~d}$ of irrigation frequency, T5 $\left(\mathrm{RS}_{1} \mathrm{I}_{15}\right)$ $=\mathrm{RS} @ 1 \mathrm{t} / \mathrm{hm}^{2}$ with $15 \mathrm{~d}$ of irrigation frequency, T6 $\left(\mathrm{RS}_{1} \mathrm{I}_{22}\right)=\mathrm{RS} @ 1 \mathrm{t} / \mathrm{hm}^{2}$ with $22 \mathrm{~d}$ of irrigation frequency, T7 $\left(\mathrm{RS}_{2} \mathrm{I}_{7}\right)=\mathrm{RS} @ 2 \mathrm{t} / \mathrm{hm}^{2}$ with $7 \mathrm{~d}$ of irrigation frequency,T8 $\left(\mathrm{RS}_{2} \mathrm{I}_{15}\right)=\mathrm{RS} @ 2 \mathrm{t} / \mathrm{hm}^{2}$ with $15 \mathrm{~d}$ of irrigation frequency and T9 $\left(\mathrm{RS}_{2} \mathrm{I}_{22}\right)=\mathrm{RS} @ 2 \mathrm{t} / \mathrm{hm}^{2}$ and $22 \mathrm{~d}$ of irrigation frequency. Different letters denoted significant differences between treatments at $p<0.05$ and error bars indicate the standard deviation (SD) of the mean value.

Figure 4 Mean soil bulk density of before and after experiment under all treatments

\subsubsection{Porosity of soil}

The results of average porosity of composite soil samples were presented in Figure 5. The average porosity of soil significantly increased after the treatments at different rice straw mulching rates and irrigation frequencies. It was revealed that the highest and lowest mean soil porosities were 35.8 and $33.1 \%$ under $\mathrm{RS}_{0} \mathrm{I}_{15}$ and $\mathrm{RS}_{1} \mathrm{I}_{22}$ treatments, respectively. However, maximum soil porosity increase was $16 \%$ under $\mathrm{RS}_{1} \mathrm{I}_{15}$, whereas minimum soil porosity

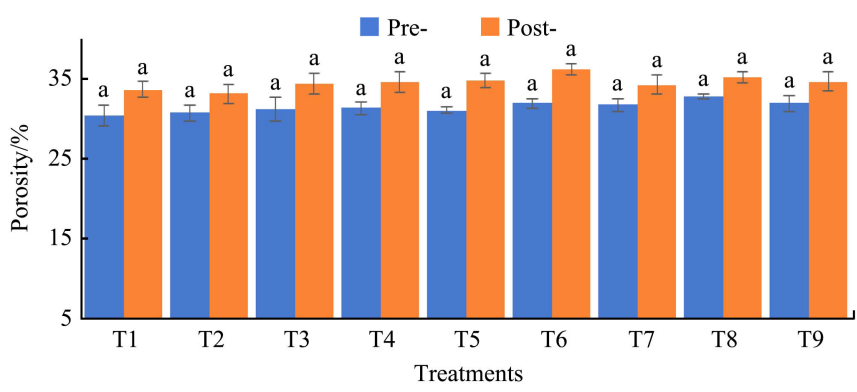

Note: $\mathrm{T} 1(\mathrm{RS} 0 \mathrm{I} 7)=$ no RS with $7 \mathrm{~d}$ of irrigation frequency, $\mathrm{T} 2\left(\mathrm{RS}_{0} \mathrm{I}_{15}\right)=$ no RS with $15 \mathrm{~d}$ of irrigation frequency, T3( $\left.\mathrm{RS}_{0} \mathrm{I}_{22}\right)=$ no RS with $22 \mathrm{~d}$ of irrigation frequency, T4 $\left(\mathrm{RS}_{1} \mathrm{I}_{7}\right)=\mathrm{RS} @ 1 \mathrm{t} / \mathrm{hm}^{2}$ with $7 \mathrm{~d}$ of irrigation frequency, T5 $\left(\mathrm{RS}_{1} \mathrm{I}_{15}\right)$ =RS@1 t/hm ${ }^{2}$ with $15 \mathrm{~d}$ of irrigation frequency, T6 $\left(\mathrm{RS}_{1} \mathrm{I}_{22}\right)=\mathrm{RS} @ 1 \mathrm{t} / \mathrm{hm}^{2}$ with $22 \mathrm{~d}$ of irrigation frequency, T7 $\left(\mathrm{RS}_{2} \mathrm{I}_{7}\right)=\mathrm{RS} @ 2 \mathrm{t} / \mathrm{hm}^{2}$ with $7 \mathrm{~d}$ of irrigation frequency,T8 $\left(\mathrm{RS}_{2} \mathrm{I}_{15}\right)=\mathrm{RS} @ 2 \mathrm{t} / \mathrm{hm}^{2}$ with $15 \mathrm{~d}$ of irrigation frequency and T9 $\left(\mathrm{RS}_{2} \mathrm{I}_{22}\right)=\mathrm{RS} @ 2 \mathrm{t} / \mathrm{hm}^{2}$ and $22 \mathrm{~d}$ of irrigation frequency. Different letters denoted significant differences between treatments at $p<0.05$ and error bars indicate the standard deviation (SD) of the mean value.

Figure 5 Porosity of soil before and after experiment under nine treatments 
increase was occurred under T5 (RS@ 2 t/ $\mathrm{hm}^{2}$ with $15 \mathrm{~d}$ of irrigation frequency).

\subsubsection{Infiltration rate}

Figure 6 presented the results of infiltration rate of the soil. Before the cultivation of crop, minimum infiltration was $2.50 \mathrm{~cm} / \mathrm{h}$ under $\mathrm{T} 2\left(\mathrm{RS}_{0} \mathrm{I}_{15}\right)$. But after applying the different rice straw mulching rates and irrigation frequencies, it significantly decreased under all treatments. The maximum decrease of $9.45 \%$ was found under $\mathrm{RS}_{0} \mathrm{I}_{7}$ and $\mathrm{RS}_{1} \mathrm{I}_{7}$ treatments respectively, whereas the minimum reduction of $7.50 \%$ was found under $\mathrm{RS}_{2} \mathrm{I}_{7}$ treatment.

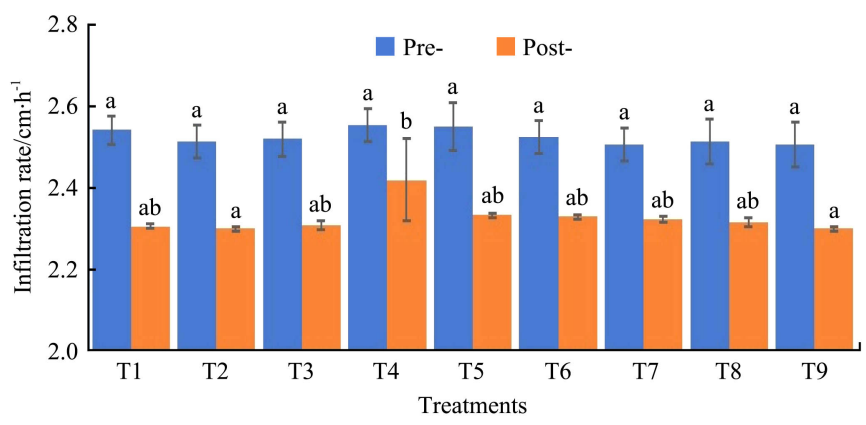

Note: $\mathrm{T} 1(\mathrm{RS} 0 \mathrm{I} 7)=$ no RS with $7 \mathrm{~d}$ of irrigation frequency, $\mathrm{T} 2\left(\mathrm{RS}_{0} \mathrm{I}_{15}\right)=$ no RS with $15 \mathrm{~d}$ of irrigation frequency, $\mathrm{T} 3\left(\mathrm{RS}_{0} \mathrm{I}_{22}\right)=$ no RS with $22 \mathrm{~d}$ of irrigation frequency, T4 $\left(\mathrm{RS}_{1} \mathrm{I}_{7}\right)=\mathrm{RS} @ 1 \mathrm{t} / \mathrm{hm}^{2}$ with $7 \mathrm{~d}$ of irrigation frequency, T5 $\left(\mathrm{RS}_{1} \mathrm{I}_{15}\right)$ =RS@1 t/hm ${ }^{2}$ with $15 \mathrm{~d}$ of irrigation frequency, T6 $\left(\mathrm{RS}_{1} \mathrm{I}_{22}\right)=\mathrm{RS} @ 1 \mathrm{t} / \mathrm{hm}^{2}$ with $22 \mathrm{~d}$ of irrigation frequency, T7 $\left(\mathrm{RS}_{2} \mathrm{I}_{7}\right)=\mathrm{RS} @ 2 \mathrm{t} / \mathrm{hm}^{2}$ with $7 \mathrm{~d}$ of irrigation frequency,T8 $\left(\mathrm{RS}_{2} \mathrm{I}_{15}\right)=\mathrm{RS} @ 2 \mathrm{t} / \mathrm{hm}^{2}$ with $15 \mathrm{~d}$ of irrigation frequency and T9 $\left(\mathrm{RS}_{2} \mathrm{I}_{22}\right)=\mathrm{RS} @ 2 \mathrm{t} / \mathrm{hm}^{2}$ and $22 \mathrm{~d}$ of irrigation frequency. Different letters denoted significant differences between treatments at $p<0.05$ and error bars indicate the standard deviation (SD) of the mean value.

Figure 6 Infiltration Rate of soil before and after experiment under all treatments

\subsection{5 $\mathrm{pH}$ of soil sample}

The $\mathrm{pH}$ of experimental soil before and after the crop growth was presented in Figure 7. The maximum value before the experiment was measured as 8.26 under T4. After experiment, $\mathrm{pH}$ of soil significantly decreased $(p<0.05)$ under all treatments, ranged from 8.26 to 7.76. The maximum and minimum reductions were $7.78 \%$ and $6.77 \%$ under $\mathrm{RS}_{1} \mathrm{I}_{15}$ and $\mathrm{RS}_{2} \mathrm{I}_{22}$ treatments, respectively.

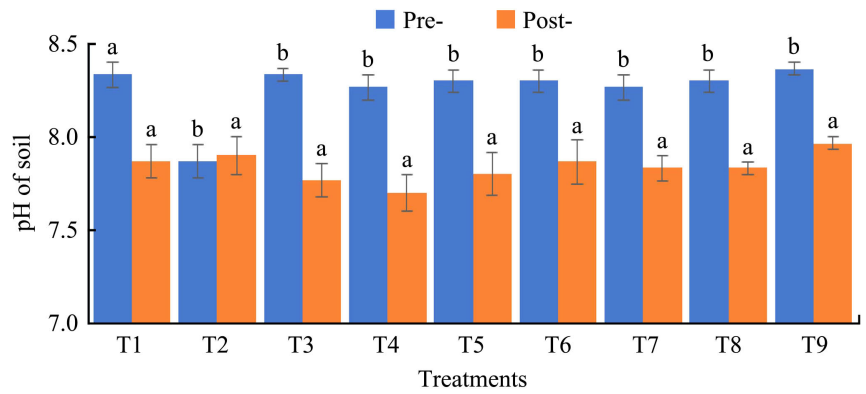

Note: $\mathrm{T} 1(\mathrm{RS} 0 \mathrm{I} 7)=$ no RS with $7 \mathrm{~d}$ of irrigation frequency, $\mathrm{T} 2\left(\mathrm{RS}_{0} \mathrm{I}_{15}\right)=$ no RS with $15 \mathrm{~d}$ of irrigation frequency, $\mathrm{T} 3\left(\mathrm{RS}_{0} \mathrm{I}_{22}\right)=$ no RS with $22 \mathrm{~d}$ of irrigation frequency, T4 $\left(\mathrm{RS}_{1} \mathrm{I}_{7}\right)=\mathrm{RS} @ 1 \mathrm{t} / \mathrm{hm}^{2}$ with $7 \mathrm{~d}$ of irrigation frequency, T5 $\left(\mathrm{RS}_{1} \mathrm{I}_{15}\right)=\mathrm{RS} @ 1 \mathrm{t} / \mathrm{hm}^{2}$ with $15 \mathrm{~d}$ of irrigation frequency, T6 $\left(\mathrm{RS}_{1} \mathrm{I}_{22}\right)=\mathrm{RS}$ (a) $1 \mathrm{t} / \mathrm{hm}^{2}$ with $22 \mathrm{~d}$ of irrigation frequency, T7 $\left(\mathrm{RS}_{2} \mathrm{I}_{7}\right)=\mathrm{RS} @ 2 \mathrm{t} / \mathrm{hm}^{2}$ with $7 \mathrm{~d}$ of irrigation frequency,T8 $\left(\mathrm{RS}_{2} \mathrm{I}_{15}\right)=\mathrm{RS} @ 2 \mathrm{t} / \mathrm{hm}^{2}$ with $15 \mathrm{~d}$ of irrigation frequency and $\mathrm{T} 9\left(\mathrm{RS}_{2} \mathrm{I}_{22}\right)=\mathrm{RS} @ 2 \mathrm{t} / \mathrm{hm}^{2}$ and $22 \mathrm{~d}$ of irrigation frequency. Different letters denoted significant differences between treatments at $p<0.05$ and error bars indicate the standard deviation (SD) of the mean value.

Figure $7 \mathrm{pH}$ of soil before and after experiment under nine treatments

\subsubsection{Electrical conductivity of soil $\left(\mathrm{EC}_{\mathrm{e}}\right)$}

Figure 8 indicated the average electrical conductivity of the soil saturation extract $\left(\mathrm{EC}_{\mathrm{e}}\right)$ of different soil depths before and after the experiment. The $\mathrm{EC}_{\mathrm{e}}$ maximum and minimum mean values before the experiment were $1.083 \mathrm{dS} / \mathrm{m}$ and $1.046 \mathrm{dS} / \mathrm{m}$ under $\mathrm{RS}_{2} \mathrm{I}_{7}$ and $\mathrm{RS}_{2} \mathrm{I}_{15}$ treatments, respectively. After experiment, $\mathrm{EC}_{\mathrm{e}}$ values significantly decreased $(p<0.05)$ under all treatments, maximum reduction of $12.4 \%(0.133 \mathrm{dS} / \mathrm{m})$ was found under RS @ $1 \mathrm{t} / \mathrm{hm}^{2}$ with $15 \mathrm{~d}$ of irrigation frequency.

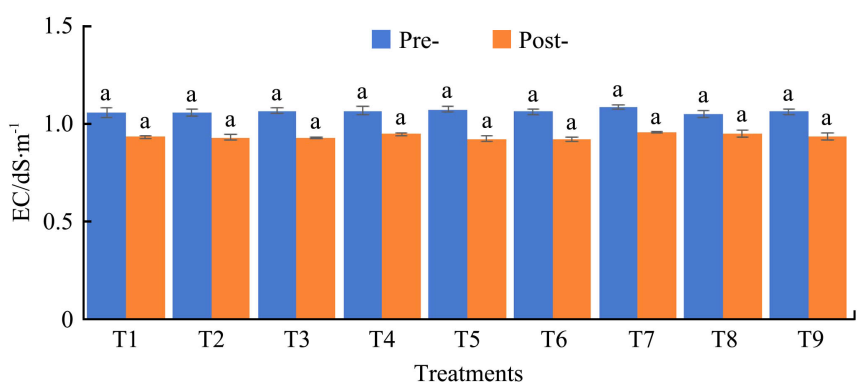

Note: $\mathrm{T} 1\left(\mathrm{RS}_{0} \mathrm{I}_{7}\right)=$ no RS with $7 \mathrm{~d}$ of irrigation frequency, $\mathrm{T} 2\left(\mathrm{RS}_{0} \mathrm{I}_{15}\right)=$ no RS with $15 \mathrm{~d}$ of irrigation frequency, T3( $\left.\mathrm{RS}_{0} \mathrm{I}_{22}\right)=$ no RS with $22 \mathrm{~d}$ of irrigation frequency, T4 $\left(\mathrm{RS}_{1} \mathrm{I}_{7}\right)=\mathrm{RS} @ 1 \mathrm{t} / \mathrm{hm}^{2}$ with $7 \mathrm{~d}$ of irrigation frequency, T5 $\left(\mathrm{RS}_{1} \mathrm{I}_{15}\right)$ $=\mathrm{RS} @ 1 \mathrm{t} / \mathrm{hm}^{2}$ with $15 \mathrm{~d}$ of irrigation frequency, T6 $\left(\mathrm{RS}_{1} \mathrm{I}_{22}\right)=\mathrm{RS} @ 1 \mathrm{t} / \mathrm{hm}^{2}$ with $22 \mathrm{~d}$ of irrigation frequency, T7 $\left(\mathrm{RS}_{2} \mathrm{I}_{7}\right)=\mathrm{RS} @ 2 \mathrm{t} / \mathrm{hm}^{2}$ with $7 \mathrm{~d}$ of irrigation frequency, T8 $\left(\mathrm{RS}_{2} \mathrm{I}_{15}\right)=\mathrm{RS} @ 2 \mathrm{t} / \mathrm{hm}^{2}$ with $15 \mathrm{~d}$ of irrigation frequency and $\mathrm{T} 9\left(\mathrm{RS}_{2} \mathrm{I}_{22}\right)=\mathrm{RS} @ 2 \mathrm{t} / \mathrm{hm}^{2}$ and $22 \mathrm{~d}$ of irrigation frequency. Different letters denoted significant differences between treatments at $p<0.05$ and error bars indicate the standard deviation (SD) of the mean value.

Figure 8 Electrical Conductivity of soil before and after experiment under different treatments

\subsection{Quality of irrigation water}

Table 3 showed the average results of $\mathrm{ECw}, \mathrm{pH}$ and SAR of irrigation water source were $1350,7.7$ and 6.70 respectively. The analysis of data revealed that the water can be termed as good quality water $(\mathrm{ECW}<1500 \mu \mathrm{S} / \mathrm{cm}, \mathrm{SAR}<10)$.

Table 3 Irrigation water quality of the experiment

\begin{tabular}{cccc}
\hline Source of water & $\mathrm{ECw} / \mu \mathrm{S} \cdot \mathrm{cm}^{-1}$ & $\mathrm{pH}$ & $\mathrm{SAR}$ \\
\hline Tube well & 1356 & 7.7 & 6.67 \\
\hline
\end{tabular}

\subsection{Irrigation water used}

Figure 9 showed the volume of water applied to the wheat crop Average volumes of water applied to the crop were $12.31 \mathrm{~m}^{3} / \mathrm{plot}$ under treatments $\mathrm{RS}_{0} \mathrm{I}_{7}, \mathrm{RS}_{1} \mathrm{I}_{7}$ and $\mathrm{RS}_{2} \mathrm{I}_{7}, 9.95 \mathrm{~m}^{3} /$ plot under treatments $\mathrm{RS}_{0} \mathrm{I}_{15}, \mathrm{RS}_{1} \mathrm{I}_{15}$ and $\mathrm{RS}_{2} \mathrm{I}_{15}$, and $8.76 \mathrm{~m}^{3} / \mathrm{plot}$ under treatments $\mathrm{RS}_{0} \mathrm{I}_{22}, \mathrm{RS}_{1} \mathrm{I}_{22}$ and $\mathrm{RS}_{2} \mathrm{I}_{22}$. These volumes were further calculated on hectare as $4924 \mathrm{~m}^{3} / \mathrm{hm}^{2}, 3980 \mathrm{~m}^{3} / \mathrm{hm}^{2}$ and $3504 \mathrm{~m}^{3} / \mathrm{hm}^{2}$ with 7,15 and $22 \mathrm{~d}$ of irrigation frequencies respectively.

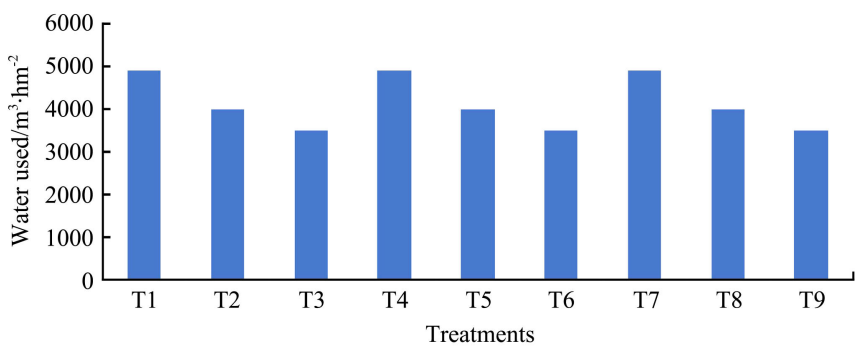

Note: $\mathrm{T} 1\left(\mathrm{RS}_{0} \mathrm{I}_{7}\right)=$ no RS with $7 \mathrm{~d}$ of irrigation frequency, $\mathrm{T} 2\left(\mathrm{RS}_{0} \mathrm{I}_{15}\right)=$ no $\mathrm{RS}$ with $15 \mathrm{~d}$ of irrigation frequency, T3( $\left.\mathrm{RS}_{0} \mathrm{I}_{22}\right)=$ no RS with $22 \mathrm{~d}$ of irrigation frequency, T4 $\left(\mathrm{RS}_{1} \mathrm{I}_{7}\right)=\mathrm{RS} @ 1 \mathrm{t} / \mathrm{hm}^{2}$ with $7 \mathrm{~d}$ of irrigation frequency, T5 $\left(\mathrm{RS}_{1} \mathrm{I}_{15}\right)$ =RS@1 $1 / \mathrm{hm}^{2}$ with $15 \mathrm{~d}$ of irrigation frequency, T6 $\left(\mathrm{RS}_{1} \mathrm{I}_{22}\right)=\mathrm{RS} @ 1 \mathrm{t} / \mathrm{hm}^{2}$ with $22 \mathrm{~d}$ of irrigation frequency, T7 $\left(\mathrm{RS}_{2} \mathrm{I}_{7}\right)=\mathrm{RS} @ 2 \mathrm{t} / \mathrm{hm}^{2}$ with $7 \mathrm{~d}$ of irrigation frequency,T8 $\left(\mathrm{RS}_{2} \mathrm{I}_{15}\right)=\mathrm{RS} @ 2 \mathrm{t} / \mathrm{hm}^{2}$ with $15 \mathrm{~d}$ of irrigation frequency and $\mathrm{T} 9\left(\mathrm{RS}_{2} \mathrm{I}_{22}\right)=\mathrm{RS} @ 2 \mathrm{t} / \mathrm{hm}^{2}$ and $22 \mathrm{~d}$ of irrigation frequency.

Figure 9 Irrigation water used

\subsection{Crop yield}

Figure 10 showed the treatment-wise average yields per plot and total yields per hectare of wheat crop cultivated in the experimental field. It indicated that the different rice straw 
mulching rates and different irrigation frequencies had a significant effect $(p<0.05)$ on average yield of wheat crop. The highest grain yield of $7114.0 \mathrm{~kg} / \mathrm{hm}^{2}$ was achieved under RS@1 t $/ \mathrm{hm}^{2}$ with $15 \mathrm{~d}$ of irrigation frequency $\left(\mathrm{RS}_{1} \mathrm{I}_{15}\right)$, and the lowest grain yield of $5730 \mathrm{~kg} / \mathrm{hm}^{2}$ was obtained under RS@2 t/ $\mathrm{hm}^{2}$ and $22 \mathrm{~d}$ of irrigation frequency $\left(\mathrm{RS}_{2} \mathrm{I}_{22}\right)$. Comparison of the rice straw mulching rates and different irrigation frequencies showed that the average crop yield was ranked as $\mathrm{RS}_{1} \mathrm{I}_{15}>\mathrm{RS}_{0} \mathrm{I}_{15}>\mathrm{RS}_{2} \mathrm{I}_{7}>$ $\mathrm{RS}_{0} \mathrm{I}_{22}>\mathrm{RS}_{1} \mathrm{I}_{22}>\mathrm{RS}_{2} \mathrm{I}_{15}>\mathrm{RS} 0 \mathrm{I} 7>\mathrm{RS}_{1} \mathrm{I}_{7}>\mathrm{RS}_{2} \mathrm{I}_{22}$ under all treatments.

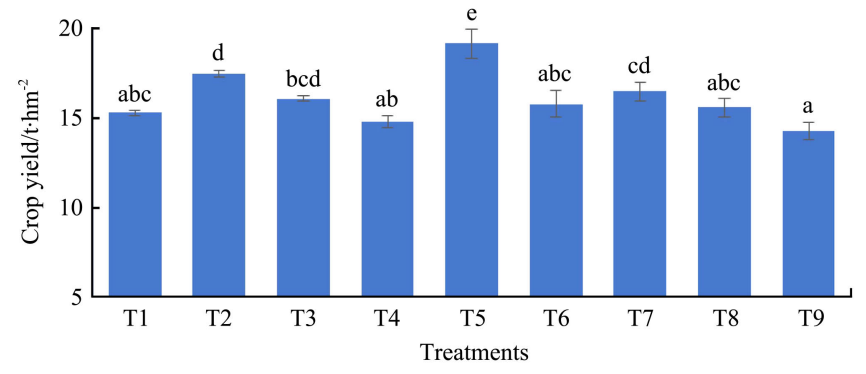

Note: $\mathrm{T} 1\left(\mathrm{RS}_{0} \mathrm{I}_{7}\right)=$ no RS with $7 \mathrm{~d}$ of irrigation frequency, $\mathrm{T} 2\left(\mathrm{RS}_{0} \mathrm{I}_{15}\right)=$ no RS with $15 \mathrm{~d}$ of irrigation frequency, T3( $\left.\mathrm{RS}_{0} \mathrm{I}_{22}\right)=$ no RS with $22 \mathrm{~d}$ of irrigation frequency, T4 $\left(\mathrm{RS}_{1} \mathrm{I}_{7}\right)=\mathrm{RS} @ 1 \mathrm{t} / \mathrm{hm}^{2}$ with $7 \mathrm{~d}$ of irrigation frequency, T5 $\left(\mathrm{RS}_{1} \mathrm{I}_{15}\right)$ =RS@1 $@ 1 / \mathrm{hm}^{2}$ with $15 \mathrm{~d}$ of irrigation frequency, T6 $\left(\mathrm{RS}_{1} \mathrm{I}_{22}\right)=\mathrm{RS} @ 1 \mathrm{t} / \mathrm{hm}^{2}$ with $22 \mathrm{~d}$ of irrigation frequency, T7 $\left(\mathrm{RS}_{2} \mathrm{I}_{7}\right)=\mathrm{RS} @ 2 \mathrm{t} / \mathrm{hm}^{2}$ with $7 \mathrm{~d}$ of irrigation frequency, T8 $\left(\mathrm{RS}_{2} \mathrm{I}_{15}\right)=\mathrm{RS} @ 2 \mathrm{t} / \mathrm{hm}^{2}$ with $15 \mathrm{~d}$ of irrigation frequency and T9 $\left(\mathrm{RS}_{2} \mathrm{I}_{22}\right)=\mathrm{RS} @ 2 \mathrm{t} / \mathrm{hm}^{2}$ and $22 \mathrm{~d}$ of irrigation frequency.

Figure 10 Total grain yield

\subsection{Crop water productivity}

Results of crop water productivity were depicted in Figure 11. Highest crop water productivity of $1.92 \mathrm{~kg} / \mathrm{m}^{3}$ was achieved under RS@ $1 \mathrm{t} / \mathrm{hm}^{2}$ with $15 \mathrm{~d}$ of irrigation frequency $\left(\mathrm{RS}_{1} \mathrm{I}_{15}\right)$, whereas the lowest crop water productivity of $1.20 \mathrm{~kg} / \mathrm{m}$ was obtained under $\mathrm{RS}_{1} \mathrm{I}_{7}$ treatment. Comparison of the rice straw mulching rates and different irrigation frequencies showed that the average crop water productivity was ranked as $\mathrm{RS}_{1} \mathrm{I}_{15}>\mathrm{RS}_{0} \mathrm{I}_{22}>\mathrm{RS}_{1} \mathrm{I}_{22}>\mathrm{RS}_{0} \mathrm{I}_{15}>$ $\mathrm{RS}_{2} \mathrm{I}_{22}>\mathrm{RS}_{2} \mathrm{I}_{15}>\mathrm{RS}_{2} \mathrm{I}_{7}>\mathrm{RS} \mathrm{I} 7>\mathrm{RS}_{1} \mathrm{I}_{7}$ under all treatments.

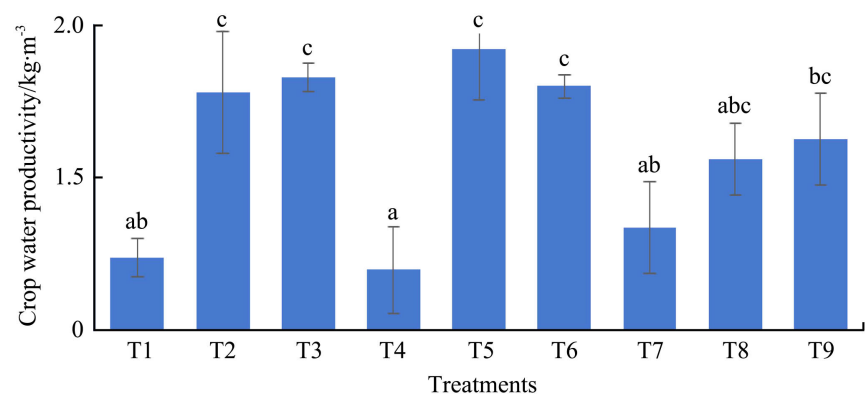

Note: $\mathrm{T} 1\left(\mathrm{RS}_{0} \mathrm{I}_{7}\right)=$ no RS with $7 \mathrm{~d}$ of irrigation frequency, $\mathrm{T} 2\left(\mathrm{RS}_{0} \mathrm{I}_{15}\right)=$ no RS with $15 \mathrm{~d}$ of irrigation frequency, T3( $\left.\mathrm{RS}_{0} \mathrm{I}_{22}\right)=$ no RS with $22 \mathrm{~d}$ of irrigation frequency, T4 $\left(\mathrm{RS}_{1} \mathrm{I}_{7}\right)=\mathrm{RS} @ 1 \mathrm{t} / \mathrm{hm}^{2}$ with $7 \mathrm{~d}$ of irrigation frequency, T5 $\left(\mathrm{RS}_{1} \mathrm{I}_{15}\right)$ =RS@1 $@ 1 / \mathrm{hm}^{2}$ with $15 \mathrm{~d}$ of irrigation frequency, T6 $\left(\mathrm{RS}_{1} \mathrm{I}_{22}\right)=\mathrm{RS} @ 1 \mathrm{t} / \mathrm{hm}^{2}$ with $22 \mathrm{~d}$ of irrigation frequency, T7 $\left(\mathrm{RS}_{2} \mathrm{I}_{7}\right)=\mathrm{RS} @ 2 \mathrm{t} / \mathrm{hm}^{2}$ with $7 \mathrm{~d}$ of irrigation frequency, T8 $\left(\mathrm{RS}_{2} \mathrm{I}_{15}\right)=\mathrm{RS} @ 2 \mathrm{t} / \mathrm{hm}^{2}$ with $15 \mathrm{~d}$ of irrigation frequency and T9 $\left(\mathrm{RS}_{2} \mathrm{I}_{22}\right)=\mathrm{RS} @ 2 \mathrm{t} / \mathrm{hm}^{2}$ and $22 \mathrm{~d}$ of irrigation frequency.

Figure 11 Crop water productivity under nine treatments

\section{Discussions}

\subsection{Effect of different rice straw mulching rates and different} irrigation frequencies on soil physicochemical properties

The results of this study indicated that rice straw incorporation with different irrigation frequencies had positive effects on soil physico-chemical characteristics, soil yields and water productivity of the wheat crop. The incorporation of rice straw showed a non-significant effect on soil texture, however, there was a slight change in the relative proportion of soil separates at different depth of the profile. Avnimelech et al. ${ }^{[38]}$ also reported similar results that the addition of rice straw improves drainage and aeration but does not effect on the texture of the clay soil. However, the incorporation of rice straw increased aggregate stability in higher or medium soils ${ }^{[39]}$. In this study, soil bulk density significantly decreased under all treatment. The maximum soil bulk density decrease of $7.3 \%$ was achieved was found under $\mathrm{RS}_{2} \mathrm{I}_{15}$ and the minimum reduction of $2.99 \%$ was found under $\mathrm{RS}_{0} \mathrm{I}_{15}$ and $\mathrm{RS}_{2} \mathrm{I}_{22}$. These findings matched with Pervaiz et al. ${ }^{[40]}$ that the bulk density decreased when adding rice straw to soil. Sharma et al. ${ }^{[1]}$ reported that applying $6 \mathrm{t} / \mathrm{hm}^{2}$ rice straw decreased bulk density from 1.44 to $1.40 \mathrm{~g} / \mathrm{cm}^{3}$ compared with no rice straw control. Similarly, Singh et al. $^{[42]}$ reported that applying rice straw improved soil bulk density and at different rates.

Singh et al. ${ }^{[42]}$ also found that applying water at different quantities did not affect soil bulk density. However, maximum soil porosity was found at $32.9 \%$ before the experiment started, but after harvest, it significantly increased to $35.8 \%$ under rice straw mulching rate at $1 \mathrm{t} / \mathrm{hm}^{2}$ with irrigation frequency of $15 \mathrm{~d}\left(\mathrm{RS}_{1} \mathrm{I}_{15}\right)$. Similar results were reported by Richard et al. ${ }^{[43]}$ that rice straw incorporation increased the porosity of soil, ranges from $25 \%$ to $40 \%$. Furthermore, porosity directly affects infiltration rate, incorporation of rice straw can increase the stability of soil. In this study, the maximum significant infiltration reduction rate of $0.24 \mathrm{~cm} / \mathrm{h}$ was found under rice straw mulching rate at $1 \mathrm{t} / \mathrm{hm}^{2}$ with $7 \mathrm{~d}$ of irrigation frequency $\left(\mathrm{RS}_{1} \mathrm{I}_{7}\right)$. There were also studies revealed that organic matter could reduce infiltration rate by changing soil structure, proportion of macro pores, and aggregate constancy ${ }^{[44]}$. Wu et al. ${ }^{[45]}$ reported that the incorporation of rice straw is a water conserving technique and decreases the infiltration rate by reducing runoff.

It was found in this study that both irrigation and organic mulches had significant influences on the electrical conductivity and $\mathrm{pH}$ of the soil. Before the experiment, the highest $\mathrm{EC}_{\mathrm{e}}$ was observed at the top layer of soil up to $30 \mathrm{~cm}$ while the lowest $\mathrm{EC}_{\mathrm{e}}$ was observed at a depth of 41-60 cm. After harvest, a decrease of soil $\mathrm{EC}_{\mathrm{e}}$ was observed in all treatments, and the highest reduction of $0.133 \mathrm{dS} / \mathrm{m}$ was found under $\mathrm{RS}_{1} \mathrm{I}_{22}$. These results were in agreement with Ashraf et al. ${ }^{[46]}$ who reported that adding straw rice straw to the loamy soil reduces the ECe of soil of up to $48 \%$. Chaudhry et al. ${ }^{[47]}$ also assessed that by applying straw mulching, the electrical conductivity of soil decreased to $53 \%$ as compared to bare soil. Furthermore, soil $\mathrm{pH}$ is one of the most vital aspects affecting metal solubility, plant nutrients uptake and movement, plant growth and many other attributes and reactions ${ }^{[48]}$. Incorporating rice straw has been reported to have the ability to buffer soil $\mathrm{pH}^{[49,50]}$. Before the experiment, the highest $\mathrm{pH}$ was observed at a depth of 0-30 $\mathrm{cm}$ down, and the lowest $\mathrm{pH}$ was observed at a depth of 40 to $60 \mathrm{~cm}$. Statistical analysis showed that the difference in $\mathrm{pH}$ was significant $(p<0.05)$ in all treatments. Results showed momentous effect of irrigation frequency and rice straw mulching on soil $\mathrm{pH}$, whereas the value of $\mathrm{pH}$ decreased from 8.36 to 7.96 . The present study agreed with research conducted by Broschat ${ }^{[51]}$, which found that rice straw can affect the soil $\mathrm{pH}$ and decreased the values in the top layer of the soil. Bolan and Hadley ${ }^{[52]}$ and Rashad et al. ${ }^{[53]}$ also assessed that soil $\mathrm{pH}$ decreased after application of rice straw due to the release of $\mathrm{H}^{+}$via nitrification during composition.

4.2 Effect of different irrigation frequencies and rice straw mulching rates on yield and water productivity of the wheat crop 
All the irrigation and mulch treatments significantly affected the grain yield of wheat. The highest grain yield of $7.7 \mathrm{t} / \mathrm{hm}^{2}$ was observed under $\mathrm{RS}_{1} \mathrm{I}_{15}$ treatment, while the lowest grain yield of $5.73 \mathrm{t} / \mathrm{hm}^{2}$ was observed under $\mathrm{RS}_{2} \mathrm{I}_{22}$, makes a difference of $1.97 \mathrm{t} / \mathrm{hm}^{2}$ (Figure 9). The output of this research is similar to previous studies conducted by Acharya et al. ${ }^{[54]}$ and Singh et al. ${ }^{[42]}$, which revealed that using different rice straw mulching rates with various irrigation intervals gave significantly better grain yield of $0.58-2.96 \mathrm{mg} / \mathrm{hm}^{2}$ than no rice straw mulch as $0.36-1.78 \mathrm{mg} / \mathrm{hm}^{2}$. Zamir et al. ${ }^{[55]}$ conducted similar research and found that rice straw mulching gave maximum yield $\left(6.33 \mathrm{t} / \mathrm{hm}^{2}\right)$ as compared to traditional methods $\left(4.92 \mathrm{t} / \mathrm{hm}^{2}\right)$. Figure 10 revealed that applying rice straw mulching and irrigation significantly $(p<0.05)$ impacted crop water productivity (CWP). Highest CWP, which was $1.93 \mathrm{~kg} / \mathrm{m}^{3}$, was observed under RS@1 t/ $/ \mathrm{hm}^{2}$ with $15 \mathrm{~d}$ of irrigation frequency $\left(\mathrm{RS}_{1} \mathrm{I}_{15}\right)$, while the minimum crop water productivity (CWP) was $1.24 \mathrm{~kg} / \mathrm{m}^{3}$ that observed in $\mathrm{T} 1\left(\mathrm{RS}_{0} \mathrm{I}_{7}\right)$. Keshaverz et al. ${ }^{[56]}$ and Ashraf et al. ${ }^{[46]}$ achieved crop water productivity values as $1.32-2 \mathrm{~kg} / \mathrm{m}^{3}$ of wheat in Mashad region of Iran. However, for comparable circumstances in Syria, Oweis and Hachum $^{[57]}$ found crop water productivity of 1.2-1.8 $\mathrm{kg} / \mathrm{m}^{3}$. Moreover, Lee et al. ${ }^{[58]}$ resulted that applying straw mulching with $15 \mathrm{~d}$ of irrigation interval get crop water productivity of 1.50 to $2.28 \mathrm{~kg} / \mathrm{m}^{3}$ of the wheat crop. These studies further proved that rice straw mulching has the capability to enhance crop water productivity.

\section{Conclusions}

This study showed the positive effects of irrigation and rice straw incorporation and physico-chemical properties of the clay loam soil. Mulching with rice straw could significantly reduce the soil bulk density, infiltration rate, soil $\mathrm{pH}$ and $\mathrm{ECe}$, while soil porosity was significantly increased. The maximum crop yield $\left(7706 \mathrm{~kg} / \mathrm{hm}^{2}\right)$ and highest water productivity $\left(1.93 \mathrm{~kg} / \mathrm{m}^{3}\right)$ were obtained under $15 \mathrm{~d}$ of irrigation frequency followed by $1 \mathrm{t} / \mathrm{hm}^{2}$ of rice straw mulching $\left(\mathrm{RS}_{1} \mathrm{I}_{15}\right)$. This study recommended that using rice straw mulching at the rate of $1 \mathrm{t} / \mathrm{hm}^{2}$ with $15 \mathrm{~d}$ of irrigation frequency provide better yield and water utilization, further increase soil fertility and crop water productivity.

\section{Acknowledgements}

This work was financially supported by National Natural Science Foundation of China Program (No. 51975255), Jiangsu Agriculture Science and Technology Innovation Fund (CX (18) 3048), and Priority Academic Program Development of Jiangsu Higher Education Institutions (No. 37(2014)).

\section{[References]}

[1] United Nations Population Division. World population prospects: the 2018 revision Population data base. http://esa.un.org/unpp. Accessed on [2018-10-01].

[2] Government of Pakistan (GOP). Economic Survey of Pakistan. 2017-2018. Ministry of Food, Agriculture and Livestock, Government of Pakistan, Statistics Division (Economic Wing), Islamabad, 2018.

[3] Ahmed Z I, Ansar M, Iqbal M, Minhas N M. Effect of different planting geometry and wheat straw mulch on performance of wheat under rainfed conditions of Pothowar. Pak J. Agric. Res, 2009; 22 (3-4): 112-115.

[4] Government of Pakistan (GOP). Economic Survey of Pakistan. 2012-2013. Ministry of Food, Agriculture and Livestock, Government of Pakistan, Statistics Division (Economic Wing), Islamabad 2013.

[5] Yoshikawa S, Cho J, Yamada H G, Hanasaki N, Kanae S. An assessment of global net irrigation water requirements from various water supply sources to sustain irrigation: rivers and reservoirs (1960-2050). Hydrol. Earth Syst. Sci, 2014; 18, 4289-4310, doi: 10.5194/hess-18-4289-2014.

[6] Lakhiar I A, Gao J, Syed T N, Chandio F A, Buttar N A. Modern plant cultivation technologies in agriculture under controlled environment: A review on aeroponics. Jr. of Plant Intr, 2018a; 13(1): 338-352.

[7] Lakhiar I A, Gao J, Syed T N, Chandio F A, Buttar N A. Monitoring and Control Systems in Agriculture Using Intelligent Sensor Techniques: A Review of the Aeroponics System. Jr. of Sens, $2018 \mathrm{~b}$.

[8] Memon M S, Ali K, Siyal A A, Guo J, Memon S A, Soomro S A. Effects of plastic sheet on water saving and yield under furrow irrigation method in semi-arid region. Int J Agric \& Biol Eng, 2018; 11(1): 172-177.

[9] Bouraima A-K, Zhang W H, Wei C F. Irrigation water requirements of rice using Cropwat model in Northern Benin. Int $\mathrm{J}$ Agric \& Biol Eng, 2015; 8(2): 58-64.

[10] Towa J J, Guo X P. Effects of irrigation and weed-control methods on growth of weed and rice. Int J Agric \& Biol Eng, 2014; 7(5): 22-33.

[11] Khokhar B, Hussain I, Khokhar Z. Effect of different irrigation frequiencies on growth and yield of different wheat genotypes in Sindh. Pakistan J. Agric. Res, 2010; 23: 3-4.

[12] Karrou M, Oweis T. Water and land productivities of wheat and food legumes with deficit supplemental irrigation in a Mediterranean environment. Agric. Water Manag, 2012; 107: 94-103.

[13] Lubna A, Ahmad N, Arshad M, Ahmad R. Effect of Different Irrigation and Management Practices on Corn Growth Parameters. Pak. J. Life Soc. Sci, 2014; 12(2): 106-113.

[14] Bouraima A-K, Zhang W H, Wei C F. Irrigation water requirements of rice using Cropwat model in Northern Benin. Int J Agric \& Biol Eng, 2015; 8(2): 58-64.

[15] Hashem, F A, Abdrabbo M A A, Hassan S A, Abul-Soud M A, Maximizing water use efficiency via different organic mulches and irrigation levels. Res. J. of Agri. \& Bio. Sci, 2014; 10(2): 109-117.

[16] Bu Y S, Shao H L, Wang J C. Effect of different mulch materials on corn seeding growth and soil nutrients and distributions. J. Soil Water Cons, 2002; 16(3): 40-42.

[17] Li X Y. Gravel-sand mulch for soil and water conservation in the semiarid loess region of northwest China. Catena, 2003; 52(2): 105-127.

[18] Tan H Q, Li M, Jie D F, Zhou Y F, Li X A. Effects of different litters on ammonia emissions from chicken manure. Int J Agric \& Biol Eng, 2019; 12(4): 27-33.

[19] Berglund R, Svensson B, Gertsson U. Impact of plastic mulch and poultry manure on plant establishment in organic strawberry production. J. Plant Nutri, 2006; 29(1): 103-112.

[20] DeSilva S H S A, Cook H F. Soil physical conditions and performance of cowpea following organic matter amelioration of sand. Common. Soil Sci. Plant Anal, 2003; 34: 1039-1058.

[21] Acharya C L, Kapur O C. Soil moisture conservation for wheat through rice straw in previous standing maize. Indian J. Agric. Sci, 1993; 63(8): 461-466.

[22] Tolk J A, Howell T A, Evett S R. Effect of mulch, irrigation, and soil type on water use and yield of maize. Soil \& Tillage Research, 1999; 50(2): 137147.

[23] Yang Y M, Liu X J, Li W Q, Li C Z. Effect of different mulch materials on winter wheat production in desalinized soil in Heilonggang region of North China. J. of Zhejiang University SCIENCE B, 2006; 7(11): 858-867.

[24] Li Y M, Chandio F A, Ma Z, Lakhiar I A, Sahito A R, Ahmad F, et al. Mechanical strength of wheat grain varieties influenced by moisture content and loading rate. Int J Agric \& Biol Eng, 2018; 11(4): 52-57.

[25] Chaudhary S, Iqbal J. Weed control and nutrient promotion in zero-tillage wheat through rice straw mulch. Pak. J. Weed Sci. Res, 2013; 19(4): 465-474.

[26] Mousavi S F, Moazzeni M, Mostafazadeh-Fard B, Yazdani M R. Effects of Rice Straw Incorporation on Some Physical Characteristics of Paddy Soils. J. Agr. Sci. Tech. 2012; 4: 1173-1183.

[27] Bouyoucos J B. Hydrometer method for making particle-size analysis of soils. Agron. J, 1962; 54: 464-465.

[28] McIntyre D S, Loveday J. Methods of analysis for irrigated soils bulk density. in Loveday, (ed) Common wealth Agricultural Bureau of Technical Communication. No 54, Farnham Royal, England.

[29] Kanwar J S, Chopra S L. Practical agriculture chemistry. Chand and Co. New dehli, 1959; 130-131. 
[30] Bouwer H. Intake rate: Cylinder infiltrometer. In Methods of Soil Analysis, Part 1. 2nd Ed. Agron. Monogr, 1986; 9: 825-844.

[31] Daniel D E. In situ hydraulic conductivity tests for compacted clay. J. of Geotech. Engr, 1989; 115(9): 1205-1226.

[32] Rowell D L. The preparation of saturation extracts and the analysis of soil salinity and sodicity in soil science methods and applications. (ed.) D.L. Rowell. Longman Group, UK, 1994.

[33] Skogerboe G V, Bennet R S, Walker W R. Installation and field use of cutthroat flumes for water management; CUSUSWASH Water Manage. Techl. Report No. 19, 1972; 1-119.

[34] Soomro A, Mirjat M S, Soomro H, Bukhari K H. Effect of different irrigation frequencies on water use efficiency, growth and cotton yield. Pak. J. Agril. Engg, Vet. Sc. 1999; 15(2)

[35] Soomro A, Mirjat M S, Oad F C, Soomro H, Samo M A, Oad N L. Effect of irrigation intervals on soil salinity and cotton yield. J. Biol. Sci, 2001; 1(6): 472-474.

[36] Isrealson $\mathrm{O} \mathrm{W}$, Hansen $\mathrm{V}$ E, Stinger $\mathrm{G}$ E. Irrigation principles and practice (4th edition). John Wiley and Sons. Inc, New York, 1980; 150p.

[37] Soomro A, Mirjat M S, Oad F C, Soomro H, Samo M A, Oad N L. Effect of irrigation intervals on soil salinity and cotton yield. J. Biol. Sci, 2001; 1(6): 472-474.

[38] Avnimelech Y, Chohen A, Shkedi D. The effect of municipal soil waste composite on the fertility of clay soils. J. Soil Tech, 1990; 3: 275-284.

[39] Doung T T T, Penfold C, Marchner P. Amending soils of different texture with six compost soil types: impact on soil nutrients availability, plant growth and nutrients uptake. Plant and Soil, 2012; 354(1-2): 197-209.

[40] Awan K S. Effect of mulch on soil physical properties and N, P, K concentration in maize (Zea mays) shoots under two tillage systems. Int. J. Agric. Bio, 2009; 11(2): 119-124.

[41] Sharma N K, Mohsin S C, Tyagi P C. Effect of Leucine mulch incorporation on soil properties under maize-wheat crop rotation. Indian J. Soil Conserv, 2009; 37(2): 123-125.

[42] Singh B, Humphrevs E, Eberbach P L, Katupitiva A, Singh Y, Kukal S S. Growth, yield and water productivity of zero tillage wheat as affected by rice straw mulch and irrigation schedule. J. Field Crops Res, 2010; 121(2): 209-225.

[43] Petrone R M, Price J S, Carey S K, Waddington J M. Statistical characterization of the spatial variability of soil moisture in a cutover peatland. Hydrological Processes, 2004; 18(1): 41-52.

[44] Karabova B, Sikorska A E, Banasik K, Kohnova S. Parameters determination of a conceptual rainfall-runoff model for a small catchment in the Carpathians. Annals of Warsaw University of Life Sciences Sggw. Land Reclamation, 2012; 44(2): 155-162.

[45] Wu L, Long T Y, Liu X, Mmereki D. Simulation of soil loss processes based on rainfall runoff and the time factor of governance in the Jialing
River Watershed, China. Environmental Monitoring and Assessment, 2012; 184(6): 3731-3748.

[46] Ashraf M, Nasir M, Bilal M, Khan M, Farah U. Characterization of ground water quality for irrigation in Tehsil and District Layyah, Punjab Pakistan. J. Nat. \& Sci, 2013; 11(4).

[47] Chaudhry B U, Bouman B A M, Singh A K. Yield and water productivity of rice-wheat on raised beds at New Delhi. Ind. Field Crops Res, 2007; 100(2-3): 229-39.

[48] Garcia-Gill J C, Ceppi S B, Velasco M I, Polo A, Senesi N. Long term effect of amendment with municipal solid waste compost on the elements and acidic functional group composition and $\mathrm{Ph}$ buffer capacity of soil humid acids. Geo. derma, 2004; 121: 135-142.

[49] Butler T J, Han K T, Muir J P, Weindrof D C, Lastly L. Dairy manure composite effect on corn silage production \& soil properties. J. Agr, 2008 100: $1541-1545$.

[50] Johnson G A, Davis J G, Qian Y L, Doesken K C. To predicting with turf with composed manure improves soil quality and protects water quality. J. Soil Sci. Soci Amer, 2006; 70: 2114-2121.

[51] Broschat TK. Effects of Mulch Type and Fertilizer Placement on Weed Growth and Soil pH and Nutrient Content. Hort Technol, 2007; 17(2): 174-178.

[52] Bolan N S, Hadley M T. Role of carbon, Nitrogen \& Sulfur cycles in Soil acidification. (Ed.) In: Rangel, Z. Handbook of soil acidity, 2003; Marcel Dekker AG, New York, USA

[53] Rashad E, Kesba M, Saleh H H, Moselhy W D. Impact of rice straw compost on microbar pollution, plant growth, Nutrients uptake and root knotnementode under greenhouse condition. Afr. J. Agri. Res, 2011; 6: 1188-1203.

[54] Acharya C L, Kapur D C. Using organic wastes as compost and mulch for potato (Solanumtuberosum) in low water retaining hill soils of Northwest India. Ind. J. Agri. Sci, 2000; 7: 306-309.

[55] Zamir M S I, Javeed H M R, Ahmed W, Ahmed A U H, Sarwar N, Shehzad M, et al. Effect of tillage and organic mulches on growth, yield and quality of autumn planted maize (zea mays 1.) and soil physical properties. Cercetări Agronomiceîn Moldova, 2013; XLVI, 2 (154).

[56] Keshavarz A, Heydari N, Ashrafi S. Management of agricultural water consumption, drought, and supply of water for future demand. Paper presented at the 7th Int'l Conference on Sustainable Development and Management of Dry-lands in 21st century, Tehran, Iran, 2003; 4-17.

[57] Oweis T, Hachum A. Reducing peak supplemental irrigation demand by extending sowing dates. J. Agri. Water Manag, 2001; 50: 109-123.

[58] Lee S, Won C H, Shin M, Park W, Choi Y, Shin J, et al. Application of surface cover and soil amendment for reduction of soil erosion from sloping field in Korea. In: Soil and water engineering. International Conference of Agricultural Engineering, CIGR- AgEng: Agriculture and engineering for healthier live. Valencia, Spain, 2012, July 8-12. 